\title{
Aloe nicholsii Gideon F.Sm. \& N.R.Crouch (Asphodelaceae): a new leptoaloe from KwaZulu-Natal, South Africa
}

\author{
Gideon F. Smith ${ }^{1,2}$ and Neil R. Crouch ${ }^{3,4}$ \\ ${ }^{1}$ Office of the Chief Director: Biosystematics Research and Biodiversity Collections Division, South African \\ National Biodiversity Institute, Private Bag X101, 0001 Pretoria, South Africa. \\ ${ }^{2}$ H.G.W.J. Schweickerdt Herbarium, Department of Plant Science, University of Pretoria, Pretoria, \\ 0002 South Africa (email: g.smith@sanbi.org.za). \\ ${ }^{3}$ Ethnobotany Unit, South African National Biodiversity Institute, P.O. Box 52099, Berea Road, 4007 Durban, \\ South Africa. \\ ${ }^{4}$ School of Chemistry, University of KwaZulu-Natal, 4041 Durban, South Africa \\ (email: n.crouch@sanbi.org.za).
}

Summary: A new species of leptoaloe, Aloe nicholsii Gideon F.Sm. \& N.R.Crouch is described from the midlands of KwaZulu-Natal, South Africa. The species shows affinities with Aloe kraussii Baker, but can be readily distinguished from it on reproductive characters: the flowers are smaller, pruinose, green below and a distinct metallic salmon-pink colour above. The flowers of A. kraussii are lemon-yellow or yellow, with green tips. Our species further differs from the unkeeled-leaf form of Aloe cooperi Baker in having much shorter flowers presented in a denser, capitate raceme, and the flower colour is not orange.

Zusammenfassung: Es wird eine neue Art von Leptaloe, Aloe nicholsii Gideon F.Sm. \& N.R.Crouch aus dem Mittelland von KwaZuluNatal, Südafrika, beschrieben. Die Art zeigt Ähnlichkeiten mit Aloe kraussii Baker, kann aber leicht aufgrund von Merkmalen der reproduktiven Organe unterschieden werden: Die Blüten sind kleiner, bereift, an der Basis grün, und zeigen darüber eine auffällige, metallische, lachsrosa Farbe. Die Blüten von A. kraussii hingegen sind zitronengelb oder gelb mit grünen Spitzen. Unsere neue Art unterscheidet sich von der ungekielt-blättrigen Form von Aloe cooperi Baker durch viel kürzere Blüten, die in einem dichteren, kopfigen racemösen Blütenstand angeordnet sind; darüberhinaus sind die Blüten nicht orange.

\section{Introduction}

A number of new species of grass aloes and leptoaloes have recently been described from South Africa's immensely rich grasslands (Smith, 2003; Van Jaarsveld \& Van Wyk, 2006; Klopper \& Smith, 2010). As the leaves of species in these two summer-flowering aloe groups are quite cryptic in resembling the blades of true grasses, non-flowering representatives are easily overlooked. However, more such taxa will likely come to light in the course of further exploration of these highly productive landscapes. We describe a new leptoaloe (Figure 1) known from a restricted region in the high altitude grasslands of Zululand, from near Babanango (Figure 2). It was first collected at the end of the $20^{\text {th }}$ century from residual grassland patches in a region largely transformed to commercial tree plantations of Acacia mearnsii and Eucalyptus spp. Affinities between the new species and Aloe kraussii Baker (sensu Reynolds, 1950) are noted, and differences highlighted in Table 1.

Aloe nicholsii Gideon F.Sm. \& N.R.Crouch spec. nov.

Aloe nicholsii a A. kraussii floribus parvioribus pruinosis infra virosis supra perspicue metallicosalmoneis, nec floribus citrinis vel luteis apicibus viridibus, differt. Praeterea a forma A. cooperi foliis non carinatis differt floribus perbrevioribus in racemo capitato densiore dispositis coloreque florum non aurantiaca.

Type: Republic of South Africa, KwaZulu-Natal, 2831 (Nkandla): Near Babanango, in rocky grassland adjacent to the R68, 1,290 m, (-AC), 17-02-2010, N. Crouch 1270, (PRE, holo., $\mathrm{NH}$ iso.). 
Table 1. Differences between Aloe nicholsii and A. kraussii.

\begin{tabular}{|lll|}
\hline Character & A. nicholsii & A. kraussii \\
\hline Clumping & solitary or in clumps of up to 40 heads & solitary or in clumps with $<10$ heads \\
\hline Stem & $\pm 60(-140) \mathrm{mm}$ & acaulescent or very short $(-50 \mathrm{~mm})$ \\
\hline Leaves & flaccidly spreading, narrowly linear-acuminate & erectly spreading, broadly linear-acuminate \\
\hline Phenology & January to March & November to February \\
\hline Flowers & $\begin{array}{l} \pm 3-16 \mathrm{~mm} \text { long, metallic salmon-pink } \\
\text { above to green below, lightly pruinose }\end{array}$ & $\begin{array}{l} \pm 16-18 \mathrm{~mm} \text { long, lemon-yellow to } \\
\text { yellow, green-tipped, not pruinose }\end{array}$ \\
\hline Androecium & $\begin{array}{l}\text { filaments included, anthers included } \\
\text { or very slightly exserted }\end{array}$ & $\begin{array}{l}\text { filaments exserted, anthers exserted to } \\
\text { to } 3 \mathrm{~mm}\end{array}$ \\
\hline
\end{tabular}

Small to medium-sized, herbaceous, slowgrowing, succulent, perennial, grass aloe, total height excluding inflorescence $\pm 300-360 \mathrm{~mm}$, usually clumped, up to 40 heads, sometimes solitary, a single head at mid-rosette up to $160 \mathrm{~mm}$ in diameter. Roots cylindrical when young, becoming fusiform with age, central portion $8(-10) \mathrm{mm}$ in diameter. Stems short, stout, \pm 60(-140) $\mathrm{mm}$ long, 20-45 $\mathrm{mm}$ in diameter. Leaves few, distichous becoming semi-rosulate, 9-15, not persistent when dry, narrowly linearattenuate, tapering to apex, 200-460 $\mathrm{mm}$ long, 20-53 mm broad at base, basally sheathing, flaccidly spreading; upper surface distinctly and consistently concave, canaliculate, mid-green to light yellowish green, occasionally with few scattered white spots towards base, smooth; lower surface convex, mid-green to light yellowish green, scattered white spots common towards base; margins with a coarse, faintly ivorycoloured edge, marginal teeth more or less absent, if present, tiny, widely spaced, harmless,

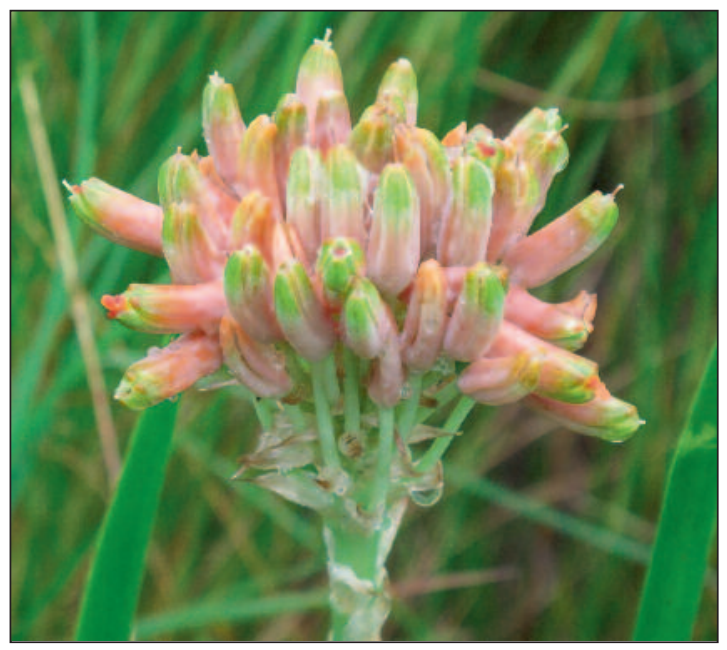

Figure 1. Densely capitate raceme showing the characteristic flower colour of A. nicholsii. Photo: Neil Crouch. triangular; ivory-coloured to greenish white, $<0.5 \mathrm{~mm}$ long towards base of leaf, becoming increasingly smaller towards tip of leaf, $5-10 \mathrm{~mm}$ distant, \pm unevenly and widely spaced; dry leaf sap translucent. Inflorescence an unbranched raceme, 300-460 $\mathrm{mm}$ tall, as tall as or exceeding the height of rosette; each rosette producing up to 3 racemes, peduncle sparsely sterile bracteate, denser towards apical part of inflorescence, bracts varying from thickened, somewhat fleshy, light yellowish green with very broad, white margins to light salmon-brown, papery, central part same colour as peduncle when succulent, many-nerved, 18-170 $\mathrm{mm}$ long, $10 \mathrm{~mm}$ broad at base, tapering to a sharp, harmless tip. Peduncle basally plano-convex, cylindrical above, 260-360 $\mathrm{mm}$ long, 6-8 $\mathrm{mm}$ broad at base, light yellowish green, dusty bloom lacking. Racemes densely capitate, the flowering portion $30-35 \mathrm{~mm}$ long, $50-60 \mathrm{~mm}$ in diameter; buds erect to suberect, congested at apex, lowest open flowers suberect to horizontal. Floral bracts amplexicaul around pedicel, large, light yellowish green, somewhat fleshy, to salmon-brown, papery, with 4-7 prominent mid-green or light brown nerves, $10-26 \mathrm{~mm}$ long. Pedicels $25-30 \mathrm{~mm}$ long. Flowers zygomorphic, unscented, small, 13-16 mm long, slightly stipitate at base, tubular-cymbiform, lightly pruinose, tricoloured, salmon-pink above, greenish below, tip extremity purplish-brown, enlarging towards throat and forming a very slightly open, distinctly upturned mouth; buds similar to open flowers, $5 \mathrm{~mm}$ in diameter in middle; buds and flowers not trigonously or cylindrically indented above ovary; outer segments larger than inner segments, lorate to long-triangular, free for most of their length, basally fused for $\pm 0.5-1.0 \mathrm{~mm}$, free portion with a prominent central nerve, borders the same colour as tepal blade, acute, segment margins folded lengthwise, apex slightly incurved; inner segments narrower than outer, with yellowish white border and more obtusely spreading apex, free for most of their 

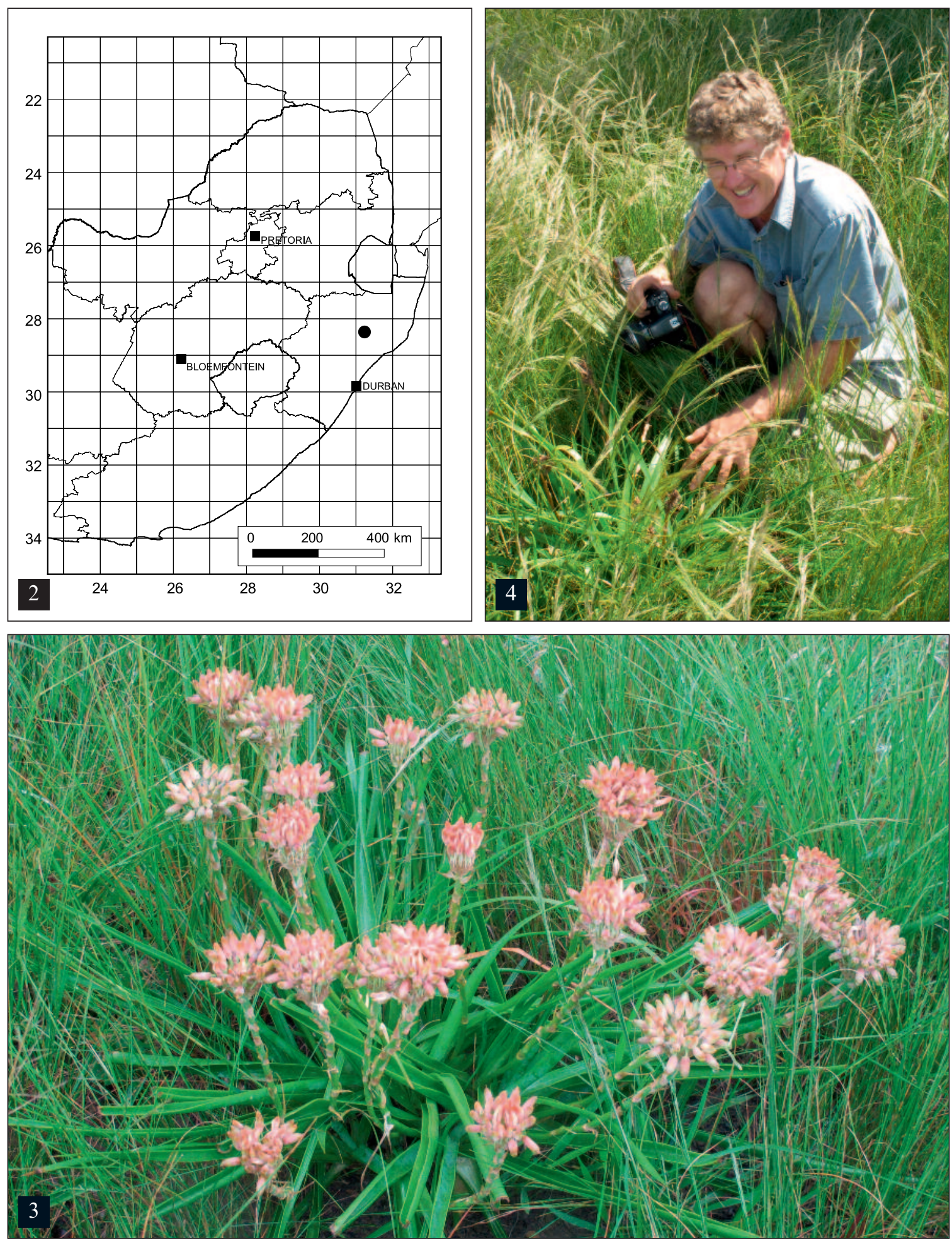

Figure 2. Known geographical distribution range of $A$. nicholsii, $\bullet$. Figure 3. Flowering clump of $A$. nicholsii in its grassland habitat, Babanango, South Africa. Photo: Neil Crouch. Figure 4. Geoff Nichols at the type locality with a non-flowering A. nicholsii, March 2009. Photo: Neil Crouch. 
length. Stamens 6, hypogynous; filaments cylindrically thread-like to very slightly flattened, light yellow, 11-13 $\mathrm{mm}$ long, all 6 of \pm equal length, not exserted; anthers small, $1.0 \mathrm{~mm}$ long, bright orange, versatile, included or only very slightly exserted. Ovary $3-5 \mathrm{~mm}$ long, $2 \mathrm{~mm}$ in diameter, light green; style short, $8 \mathrm{~mm}$ long, minutely capitate; stigma small, becoming exserted during female phase of flower. Fruit an erect, bright green, trilocular capsule, cylindrical, 17-19(-22) $\mathrm{mm}$ long, 9-10 $\mathrm{mm}$ in diameter, apically truncate, dry remains of tepals persisting around fruit for a long time, dehiscing loculicidally, chartaceous to woody when dry. Seeds, dark greyish brown, angled, laterally compressed, with off-white wing stretching around periphery of seed, 2.5-3.0 mm long. Flowering time January to March, peaking in February. Chromosome number unknown. (See Figures 1 and 3.)

\section{Habitat and conservation status}

Plants were collected in full sun in open rocky grassland of Northern Zululand Sourveld (SVl 22) (Mucina et al., 2006) at an altitude of $\pm 1,290 \mathrm{~m}$, growing in a rocky, clay-loam substrate. Although low rock outcrops are present at the type locality the aloes were not observed to take particular refuge amongst these. Plants found growing in association with $A$. nicholsii were Syncolostemon parviflorus, Searsia dentata, Rhynchosia woodii and Ochna serrulata in the vicinity of low rocky sites, and Thunbergia atriplicifolia, Gladiolus ecklonii, Watsonia densiflora and Schizocarphus nervosus in more exposed grasslands. About 80 individual plants or clumps (Figure 3) were found at the type locality (Figure 4), occupying an area of approximately $2,000 \mathrm{~m}^{2}$. This represents the full extent of the currently known population. An earlier record (Nichols s.n. NU) indicates that a decade ago small clumps were frequent along the R68 roadside in that region. However, four excursions along the R68 made during the past two flowering seasons failed to yield a single specimen; notably, the verge is now largely degraded. Although further populations may in time be found, particularly in the nearby Ophate Game Reserve, it would be prudent to presently regard the species' Red List status as Data Deficient.

\section{Eponymy}

This species is named for Mr Geoff Nichols of South Africa (Figure 4), who made the first known collection of this new species, and who through initiating and establishing the
Silverglen Nursery in Durban pioneered the conservation-through-cultivation of many endangered medicinal and rare plants of KwaZuluNatal and Pondoland.

\section{Additional specimen examined}

2831 (Nkandla): On road verge between Eshowe and Babanango (-AC), G. Nichols s.n. (NU), 14-2-1999.

\section{Acknowledgements}

We thank Dr Otto A. Leistner, formerly of the South African National Biodiversity Institute (SANBI), Pretoria, South Africa, for providing the Latin diagnosis, and Ms Hannelie Snyman and Ms Hester Steyn of SANBI for preparing the map. Prof. T. Edwards (then Curator of NU) is thanked for bringing the original Nichols specimen to the attention of one of us (NC), and for commenting on its novelty. For assistance with fieldwork during March 2009, both Mr Geoff Nichols and Mr Gareth Chittenden are gratefully acknowledged.

\section{References}

Craib, C. (2005). Grass aloes of the South African veld. Umdaus Press, Hatfield, Pretoria.

Klopper, R.R. \& SMith, G.F. (2010). Aloe neilcrouchii, a new robust Leptoaloe from KwaZulu-Natal, South Africa. Bothalia 40: 117-120.

Mucina, L., Hoare, D.B., Lötter, M.C., Du Preez, J., Rutherford, M.C., ScotT-Shaw, C.R., Bredenkamp, G.J., Powrie, L.W., ScotT, L., Camp, K.G.T., Cilliers, S.S., Bezuidenhout, H., Mostert, T.H., Siebert, S.J., Winter, P.J.D., Burrows, J.E., Dobson, L., Ward, R.A., Stalmans, M., Oliver, E.G.H., Siebert, F., Schmidt, E., Kobisi, K. \& Kose, L. (2006). Grassland Biome. In L. Mucina \& M.C. Rutherford. The vegetation of South Africa, Lesotho and Swaziland. Strelitzia 19: 349-436.

Reynolds, G.W. (1950). Aloes of South Africa. Aloes of South Africa Book Fund, Johannesburg.

Smith, G.F. (2003). Aloe craibii Gideon F.Sm. (Asphodelaceae: Alooideae): a new species of grass aloe from the Barberton Centre of Endemism, Mpumalanga, South Africa. Bradleya 21: 25-28.

VAN JAARSVELD, E.J. \& VAN WyK, A.E. (2006). Aloe challisii, a new cliff-dwelling aloe from Mpumalanga, and a checklist of the obligate cliff-dwelling aloes in South Africa and Namibia. Aloe 43: 36-41. 